\title{
Climate talks edge towards twin-track future
}

MONTREAL

For many of the delegates from nearly 200 nations meeting in Montreal this week to discuss how to prevent climate change, the key question is how to get the United States to talk about limiting greenhouse-gas emissions.

As Nature went to press, the halls of the Palais des Congrès were rumbling with a report that the conference president, Canada's environment minister Stéphane Dion, would propose structuring climate-change strategy through the United Nations Framework Convention on Climate Change. Such an approach would be in addition to the Kyoto Protocol, which limits greenhouse-gas emissions for developed countries. The United States is a party to the convention, but not the protocol.

Such a strategy could free countries to pursue a range of options for fighting global warming, says Elliot Diringer, director of international strategies for the Pew Center on Global Climate Change, based in Arlington, Virginia. These options might include technologies such as carbon capture and storage, or fuel-economy standards for the automobile industry. "There's a rich array of thinking out here right now," says Diringer. "What we need is some window to introduce that thinking into the formal process."

IMAGE
UNAVAILABLE
FOR COPYRIGHT
REASONS

Thering is the convention's first twintrack meeting. One track addresses the parties to the convention, and the other addresses the 157 nations that have ratified the Kyoto agreement. In the first week of negotiations, delegates finalized the rule book for the Kyoto Protocol, known as the Marrakesh Accords.

Australia and the United States are some of the holdouts from the Kyoto agreement. Developing countries such as China and India - some of the world's fastest-growing emitters - are not bound by emission caps, although they are parties to the protocol. The first commitment period for reducing emissions under Kyoto expires in 2012.

Some delegates welcome twin-track talks as a step towards a process outside Kyoto, which many feel has had an inauspicious start. The Clean Development Mechanism, for example, an arm of the protocol intended to promote sustainable development in developing countries, has been slow to gain momentum. Few countries are expected to meet their current targets, making it less likely that they will take on bigger emissions cuts in the next commitment period.

But some countries could stall any forward-looking process. In a statement on 29 November, Harlan Watson, lead negotiator for the US delegation, said that his country is opposed to discussing commitments beyond 2012. Watson reaffirmed the US position to engage instead in technological innovations on the home front and partnerships with smaller clusters of countries.

Such an approach does not please many. “They are dearly not moving forward on longterm cooperative action," says a spokesperson for the European Union presidential delegation, who asked to remain anonymous.

Many observers feel that a good finish for the conference, which runs until 9 December, would be a green light to discuss future options under the convention. ${ }^{\alpha}$ The most that we can hope for here is some decision to allow for parties to begin thinking about these options in a formal context," says Diringer. "It's an incremental step, but it's an essential step." Amanda Haag

\section{Prospect of stricter timekeeping alarms US biologists}

\section{WASHINGTON}

Proposed guidelines for federally funded US researchers, recommending more detailed accounting of how they spend their time, will, if approved, draw howls of protest from labs across the United States.

The office of the inspector general at the Department of Health and HumanServices, parent department to the main US biomedical-research agencies, released the draft guidelines on 28 November.

The guidelines setout general principles for a programme to prevent and catch fraud, and identified three risk areas: time

\author{
reporting, sloppy accounting \\ between grants, and not reporting \\ financial support from other \\ sources. Comments will be \\ accepted until 28 December. \\ In the section on time reporting \\ the guidelines say, "Many \\ researchers have multiple \\ responsibilities - sometimes \\ involving teaching, research, \\ and clinical work - that must \\ be accurately measured and \\ monitored. In the course of \\ a researcher's workday, the \\ separation between these areas of \\ activity can sometimes be hard to \\ discern, which heightens the need \\ tohave effective timekeeping \\ systems."
}

\author{
MostUS researchers donot keep \\ daily time logs, but estimate in \\ advance whatpercentage of their \\ time they will spend on a project. \\ That estimate is used to determine \\ how much of their salary and \\ benefits the grant pays for. \\ The spectre of a punch-clock \\ in the lab appals many scientists. \\ "I think it would be a major \\ impediment to Americanscience," \\ says BethLevine, a specialist in \\ infectious diseases at the \\ University of Texas Southwestern \\ Medical Center in Dallas. \\ "There is some very prescriptive \\ language in there that gives us \\ concern," adds Tony DeCrappeo, \\ president of the Council on
}

\section{Government Relations, a} Washington DC-based association of research universities working to shapeagency policy.

The guidance also calls for a compliance officer and compliance committee for eachinstitution.

The guidelines are not mandatory, but the inspector general and the USDepartment of Justice might use them in judging fraud cases.

Glenn Baly, spokesman for the inspector general's office, says not to fret. "These are general guidelines. The details would be worked out by the agencies and organizations involved." Emma Marris 